\title{
Alterations of Some MicroRNAs Expression in Hepatocellular Carcinoma Cell Lines by Sodium Butyrate
}

\author{
REHAM SROUR, M.Sc.*; NADIA EL-GUENDY, Ph.D.*; MONA MOHAMED MOSTAFA, Ph.D.**; \\ MEDHAT SALAH EL-HALAWANY, Ph.D.** and ABD EL-HADY ALI ABD EL-WAHAB, Ph.D.* \\ The Department of Cancer Biology, National Cancer Institute* and the Department of Zoology, Faculty of Science**, \\ Cairo University
}

\begin{abstract}
Background: Epigenetic gene regulation is important in human cancer.

Aim of Study: We investigated the possible role of acetylation level in the regulation of microRNAs (miRNAs) expression in hepatocellular carcinoma.

Material and Methods: We first determined the inhibitory concentration (IC20, IC35 and IC50) of the histone deacetylase inhibitor Sodium Butyrate (SB) in HepG2 and Huh7 cells. Then, we analyzed the expression level of five miRNAs (miR133b, miR-122-5p, miR-26a-5p, miR-539-5p and miR-518f$3 p$ after treatment using qRT-PCR assay. MiRTarBase, MiROB and GeneCards databases were used for the identification of strong validated targets of examined microRNAs, and the detection of possible functions of the selected targets and related pathways.

Results: SB revealed an anti-proliferative effect in both HepG2 and Huh7 cells, with IC50 values of $6.7 \mathrm{mM}$ and $9.2 \mathrm{mM}$, respectively. MiR-133b showed up-regulation in HepG2 and miR-122-5p was down-regulated in HepG2 and Huh7 (29.5 and 1000 folds) in a dose dependent manner. MiR26a-5p exhibited decrease in its level in both cell lines at IC35, but was increased at IC50 in HepG2 cells. MiR-518f$3 p$ showed increase in its level during various doses of SB in both cell lines. Finally, miR-539-5p showed down expression in both cell lines. Prediction pathway analysis referred to the important role of each of miR-133b, miR-122-5p and miR$26 \mathrm{a}-5 \mathrm{p}$ in proliferation, apoptosis, angiogenesis and metastasis.

Conclusion: Sub-lethal doses of SB have significant effects on miRNAs expression in human hepatocellular carcinoma cells. Understanding the epigenetic regulation of miRNAs may enhance the development of therapeutic strategies against $\mathrm{HCC}$.
\end{abstract}

Key Words: HCC - microRNAs - Epigenetics - Acetylation - Sodium butyrate.

\section{Introduction}

HEPATOCELLULAR Carcinoma (HCC) is the fifth most prevalent cancer disease worldwide [1]

Correspondence to: Dr. Abd El-Hady A. Abd El-Wahab, E-Mail: abdelhady.abdelwahab@nci.cu.edu.eg
Chronic liver injury, that results in inflammation, hepatocyte regeneration, liver matrix transforming, fibrosis, and, finally, cirrhosis can cause HCC development [2] . In addition to numerous genetic causes, the development and progression of HCC is strongly correlated with epigenetic pattern of DNA and histone modifications. In the last decade, Histone Acetylases (HATs) and Histone Deacetylases (HDACs) have shown important roles in the regulation of transcription [3]. Histone Deacetylase Inhibitors (HDACi) can affect angiogenesis, cell differentiation and apoptosis [4]

Sodium Butyrate (SB) is one of the short chain fatty acids naturally formed in gastrointestinal tracts. SB can cause cell cycle arrest, apoptosis and stimulate cell differentiation in multi type of cancer cells lines notably the colon [5] breast [6], liver [7]. SB, a histone deacetylases inhibitor, can induce broad alteration in chromatin structure and expression of genes [1]. SB has been shown to inhibit proliferation in different cancer cell lines high efficiency and very low general toxicity [811].

It has been shown that histone deacetylation plays a vital role as a regulator for microRNAs (miRNAs) expression [12]. MiRNAs are a small non-coding RNAs of $\sim 22$ nucleotides that regulate gene expression machinery. There is rising attention in recognizing the harmony between miRNA expression in cancer disease, chemo-and radiosensitivity to enhance the performance of the treatment manner through prediction or modulation of sensitivity or response [13]

The goal of the present study is to investigate the effects of acetylation level alterations by SBon HCC cell lines survival and incontrolling the expression of five miRNAs, known to be involved 
incell proliferation, apoptosis, angiogenesis and metastasis.

\section{Material and Methods}

\section{Cell lines:}

The human HCC cell lines, HepG2 and Huh7 used in the current study, wereobtainedfrom VACSERA (the Egyptian Company for Production of Vaccines, Sera and Drugs). The cell lines were maintained in Dulbecco's Modified Eagle's Medium (DMEM) supplemented with $10 \%$ fetal bovine serum (Gibco,USA), 100U/ml penicillin and $100 \mathrm{~g} / \mathrm{n}$ Lstreptomycin at $37^{\circ} \mathrm{C}$ in a humidified $5 \% \mathrm{CO} 2$ incubator (Thermo Scientific, City, USA). SB was obtained from Sigma-Alderish (Merck KGaA, Germany). SB stock solution was prepared at a concentration of $250 \mathrm{mM}$ in distilled water and stored at $-20^{\circ} \mathrm{C}$.

This study was conducted at National Cancer Institute, Cairo University (NCICU) from August 2015 - December 2017.

\section{Cell viability assay:}

The cytotoxic effect of SB was determined using SulphoRhodamine-B assay (SRB) as described previously [14]. Cells were seeded onto 96well plates ( $5 \times 10^{3} /$ well) corresponding to $75 \%$ confluence, for $24 \mathrm{~h}$. The cells were treated with 7 different concentrations of SB $(0.25,0.5,2,5,6$, 8 and $12 \mathrm{mM}$ ) and incubated at $37^{\circ} \mathrm{C}$ in a humidified $5 \% \mathrm{CO} 2$ incubatorfor another $48 \mathrm{~h}$. Untreated cells (control cells) seeded in parallel in serum free media. After incubation, cell fixation was done by treatmentwith TCA to a final concentration $10 \%$ for $30 \mathrm{~min}$. SRB $(0.4 \%)$ was added for $30 \mathrm{~min}$, then cells were washed with $1 \%$ Acetic acid. $10 \mathrm{mM}$ Tris base were added and the absorbance was recorded on a microplate reader (Tecan Sunrise, Austria) at a wavelength of $570 \mathrm{~nm}$. Each treatment wasdone in triplicates. The sub-lethal inhibitory concentrations of SB (IC20, IC35 and IC50) were calculated and selected for use in the following experiments as shown in (Table 1) and Fig. (1).

\section{MiRNAsextractionand quantitative real-time} PCR analysis:

Total RNA (including miRNAs) from HepG2 and Huh7 cell lines, before and after treatment with $\mathrm{SB}$, was extracted using miRNeasy kit as described in the manufacturer's instructions (Qiagen, Germany). RNA was purified using miRNeasy MinElute spin columns (Qiagen, City, Country) then eluted in 35 RRase-free water. RNA concentrations were quantified using NanoDropOnespectrophotometer (Thermo Scientific, City,
USA). Total RNA (250ng/sample) was reversetranscribed using miScript RT kit (Qiagen). Reactions were incubated at $37^{\circ} \mathrm{C}$ for $1 \mathrm{~h}$ followed by inactivation of the reaction by incubation at $95^{\circ} \mathrm{C}$ for $5 \mathrm{~min}$.

The expression levels of miR-133b, miR-26a$5 p$, miR-122-5p, miR-518f-3p and miR-539-5p were measured using miScript SYBER Green reagent kit (Qiagen) according to the manufacturer's protocol. About 5ng of cDNA was used as template in a 10 IPCR reaction containing $1 \mathrm{X}$ SYBR Green master mix, 1XmiRNA specific forward primer, and $1 \mathrm{X}$ universal primer. The conditions for qRTPCR were as follows: $95^{\circ} \mathrm{C}$ for $10 \mathrm{~min}$, followed by 40 cycles of $95^{\circ} \mathrm{C}$ for $15 \mathrm{~s}$ and $55^{\circ} \mathrm{C}$ for $1 \mathrm{~min}$. All the RT-qPCR reactions were performed on ViiA7 real-time PCR system (Applied Biosystems, USA). All samples were performed in duplicate. U6 snRNA was used as an endogenous control for normalization. The relative expression analysis of miRNAs studied was performed using comparative Ct method [15]

\section{Data analysis:}

The obtained real time data was analysed using ${ }^{\Delta \Delta} \mathrm{Ct}$ comparative method. U6 was used as an endogenous control and its $\mathrm{Ct}$ values were subtracted from the examined miRNA Ct values to obtain $\Delta \mathrm{Ct}$. The fold of change was calculated from the following formula: Fold of change $=2-\Delta \Delta \mathrm{Ct}$.

\section{Statistical analysis:}

The significant difference in cytotoxicity assay values was evaluated using one-way ANOVA, followed by the Dunnett's multiple comparison test. Data are presented as means \pm SD. Statistical analyses were performed using GraphPad Prism Version 5 for windows (GraphPad Software Inc., city, USA). $p$-value $<0.05$ wasconsidered significant.

\section{Bioinformatics analysis:}

MiRTarBasedatabase (http://mirtarbase. mbc. nctu.edu.tw/php/index.php) (January 2018) and MirOBdatabase (http://mirob.interactome.ru/) (January 2018) were used to identify the experimentallyvalidated targetsand the related pathwaysof theexamined miRNAsinthis study. GeneCardsdatabase (http://www.genecards.org/) has been adoptedto identify possible functionsof the validated targets.

\section{Results}

In this study we investigated the cellular effects ofthree sub-lethaldoses of SB treatment on liver 
cancer cell lines (HepG2 and Huh7) survival andon the expression level of 5-selected miRNAs.

Cytotoxicity of SB on liver cancer cell lines (HepG2 and Huh7):

To determine theeffect of SB onHepG2 and Huh7, cells were exposed to 7 concentrations of SB ranging from $(0.25,0.5,2,5,6,8$, and $12 \mathrm{mM})$ for $48 \mathrm{~h}$, and then cell viability were measured using SRB assay. Our data revealed a concentrationdependent decrease in the survival rate with SB treatment Fig. (1) in both cell lines examined. Notably, HepG2 cells exhibited a higher sensitivity to SB treatment compared to Huh7. Detected IC20, IC35, and IC50 concentrations were used for further analyses Fig. (1) and (Table 1).

\section{Quantitative RT-PCR assay:}

The effect of three different concentrations of SB (IC20, IC35, and IC50) on the expression level of selected miRNAs was examined. The examined miRNAs revealed different expression level between the two cell lines (Table 2).

\section{Pathway predication:}

miRTarBase, MirOB and Gene Cards have (Janaury 2018) been searched to identify experi- mentally validated targets of selected miRNAs andtheirsuggested functions and related pathways. Interestingly, the revealedtarget genes signaling areinvolved, to some extent, incell death, proliferation and survival.

Table (1): Calculated Inhibitory Concentrations (ICs) of SB on HepG2 and Huh7 liver cell lines after 48h of incubation.

\begin{tabular}{lll}
\hline \multirow{2}{*}{$\begin{array}{l}\text { Inhibitory } \\
\text { concentration }\end{array}$} & \multicolumn{2}{c}{$48 \mathrm{~h}$ incubation } \\
\cline { 2 - 3 } & HepG2 & Huh7 \\
\hline IC20 & $2 \mathrm{mM}$ & $2.5 \mathrm{mM}$ \\
IC35 & $4.3 \mathrm{mM}$ & $6.25 \mathrm{mM}$ \\
IC50 & $6.7 \mathrm{mM}$ & $9.2 \mathrm{mM}$ \\
\hline
\end{tabular}

Table (2): Foldchange gene expression of selected miRNAsin HepG2 and Huh7 liver cells.

\begin{tabular}{lllllll}
\hline & \multicolumn{5}{c}{ Fold regulation } \\
\cline { 2 - 7 } miRNAs & \multicolumn{3}{c}{ HepG2 } & \multicolumn{4}{c}{ Huh7 } \\
\cline { 2 - 7 } & $\mathrm{IC}_{20}$ & $\mathrm{IC}_{35}$ & $\mathrm{IC}_{50}$ & $\mathrm{IC}_{20}$ & $\mathrm{IC}_{35}$ & $\mathrm{IC}_{50}$ \\
\hline miR-133b & 4.5 & 20.7 & 30.4 & -7 & -1.3 & 2.5 \\
miR-26a-5p & -4.5 & -22.2 & 16.2 & -2.5 & -5.6 & -1 \\
miR-122-5p & -29.2 & -13.9 & -4.5 & -1000 & -1.5 & 1.4 \\
miR-539-5p & -1.2 & -1.5 & -1.8 & -2.5 & -2.6 & 1.1 \\
miR-518f-3p & 27842.5 & 600 & 334.5 & 5.5 & 233.7 & 69 \\
\hline
\end{tabular}

Table (3): Examined 5-miRNAs and theiridentified target genes via miRTarBasedatabase.

\begin{tabular}{|c|c|c|c|}
\hline miRNAs & Target gene & Gene function & References \\
\hline \multirow[t]{9}{*}{ Hsa-miR-133b } & BCL2L2 & - Involved in intrinsic anti-apoptotic pathway. & {$[16,17]$} \\
\hline & MCL1 & - Acts as anti-apoptotic. & [16] \\
\hline & IGF1R & - Acts as anti-apoptotic. & [18] \\
\hline & FAIM & - Involved in extrinsic anti-apoptotic pathway. & [19] \\
\hline & FSCN1 & - Involved in metastasis. & [20] \\
\hline & EGFR & • Induces proliferation. & [21] \\
\hline & FGFR1 & - Involved in migration and angiogenesis. & [22] \\
\hline & MET & - Acts as oncogenic and involved in resistance to drug. & [23] \\
\hline & GLI1 & - Induces migration. & [24] \\
\hline \multirow[t]{5}{*}{ Hsa-miR-26a-5p } & HMGA 1 & - Involved in metastasis. & [25] \\
\hline & MTDH & - Involved in tumor cell expansion and metastasis. & [26] \\
\hline & FGF9 & - Induces cell survival, tumor growth and invasion. & [27] \\
\hline & HGF & - Involved in angiogenesis, tumorigenesis and tumor regeneration. & [28] \\
\hline & PIK3C2A & - Induces proliferation and cell survival. & [29] \\
\hline \multirow[t]{4}{*}{ Hsa-miR-122-5p } & IGF1R & $\begin{array}{l}\text { - Involved in ell growth and survival control, induces tumor transformation and } \\
\text { survival of malignant cell. }\end{array}$ & {$[30]$} \\
\hline & MAPK11 & - Involved in cellular proliferation. & [31] \\
\hline & AKT3 & $\begin{array}{l}\text { - Regulates many processes including metabolism, proliferation, cell survival, } \\
\text { growth and angiogenesis. }\end{array}$ & [32] \\
\hline & BCL2L2 & - Involved in intrinsic anti-apoptotic pathway. & [33] \\
\hline \multirow[t]{2}{*}{ Hsa- miR-539-5p } & TWIST1 & - Promotes tumor cell invasion and metastasis. & [34] \\
\hline & ZEB1 & $\begin{array}{l}\text { - Induces an Epithelial-Mesenchymal Transition (EMT) and promotes } \\
\text { tumorigenicity by repressing stemness-inhibiting microRNAs. }\end{array}$ & [35] \\
\hline \multirow[t]{4}{*}{ Hsa-miR-518f-3p } & RBM8A & - Inhibits formation of proapoptotic isoforms such as Bcl-X. & [36] \\
\hline & STK4 & - Act as pro-apoptotic kinase. & [36] \\
\hline & TYRO3 & $\begin{array}{l}\text { - Has role in controlling cell survival and proliferation, spermatogenesis, } \\
\text { immunoregulation and phagocytosis. }\end{array}$ & [36] \\
\hline & RPS6KA3 & $\begin{array}{l}\text { - Regulates diverse cellular processes such as cellular growth, motility, survival } \\
\text { and proliferation. }\end{array}$ & [36] \\
\hline
\end{tabular}




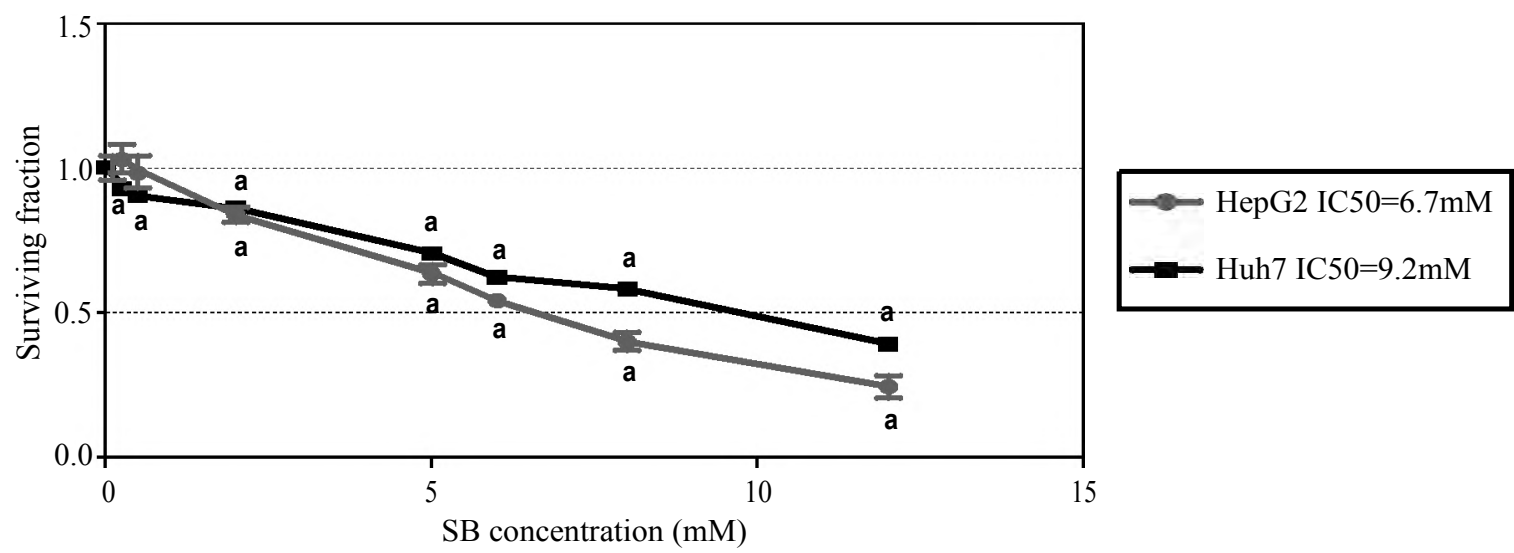

Fig. (1): Viability of HepG2 and Huh7 cells at different doses of SB treatment for $48 \mathrm{~h}$. The results are expressed as the mean \pm SD of 3 separate experiments.
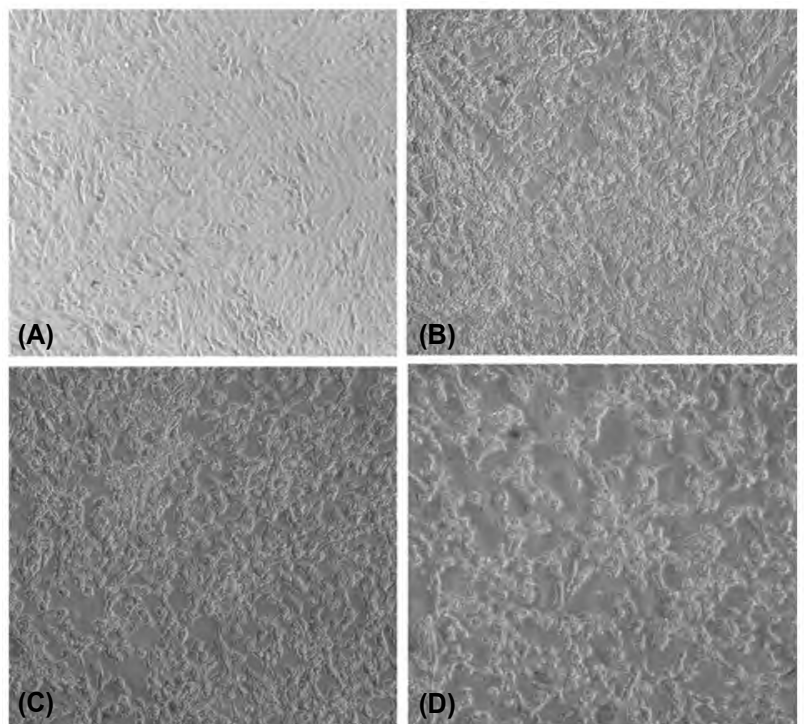

HepG2
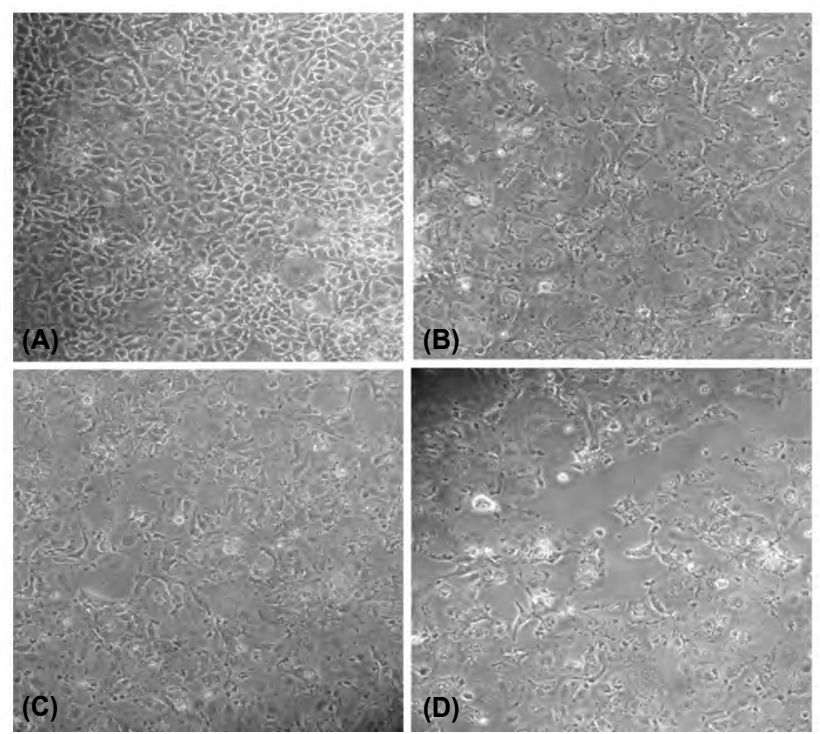

Huh7

Fig. (2): Cellular viability of HepG2 and Huh7 cells treated with different doses of SB for 48h. (A) Control untreated cells, (B) Cells treated with IC20 of SB, (C) Cells treated with IC35 SB, and (D) Cells treated with IC50 of SB.

\section{Discussion}

The histone deacetylase inhibitor (HDACi), Sodium Butyrate, is a component of short-chain fatty acids produced by anaerobic fermentation of dietary fibers in the gastrointestinal tract of mammalian species [37]. SB can inhibit cell proliferation and potentiate cancer therapy and prevention via inhibition of HDACs, that makes it a good candidate for cancer management. It has been shown that HDACi play a vital role as regulators for many miRNAs [38]. Thus, understanding their specific role could changes the therapeutic strategies for cancer.

The present data displayed decreasein cell growth of HepG2 and Huh7 liver cell lines when treated with SB in a dose-dependent manner, which is consistence with previous studies [9]. Further- more, HepG2 cells revealed higher sensitivity upon treatment with SB than Huh7 cells, their IC50 values were $6.7 \mathrm{mM}$ and $9.2 \mathrm{mM}$, respectively. Previous studies have reported that cytotoxicity of SB was in the range of $1.47 \mathrm{mM}$ to $5 \mathrm{mM}$ for HepG2 [11,39] and 2mM in Huh7 [40] which are different from our detected IC50 values. This might be due to the difference in the number of passages of each cell line. Meanwhile, the variation between the two cell linesmight be attributed to the variation in their biological and geneticcharacteristics such as difference in p53expression as well as expression of certain proteins such as $\alpha$-feto protein, and others in HepG2 cells [41].

It has been shown that SB might induce profound changes in miRNA expression of HCC cells [42]. MiRNA scan have extensive effects through regulation of a variety of genes that are involved 
in the most vital cellular processes including, differentiation and cell cycle regulation $[43,44]$.

The present data shows an up-regulation of miR-133b expression level in HepG2 cells, treated with $\mathrm{SB}$, in a dose-dependent manner whereas, it is down-regulated in Huh7 with low dose treatment. Previous studies haveshown that treatment of gastric cancer cell lines with SAHA (HDAC inhibitor) increases the expression level of miR-133b/a-3p and decreases acetylation which refers to the role of histone acetylation in regulation of miR-133b expression [21]. Our gene target analysis by GeneCards database suggests that miR-133b might have a pro-apoptotic function as it seems to target a number of anti-apoptotic genes (Table 3). This is consistent with several studies that have shown down regulation of miR-133b level in different types of cancer $[45,46]$ and this change was significantly associated with poor survival and distant metastasis in colorectal carcinoma [47]. Overexpression of miR-133b can boost apoptosis through TRAIL pathway as detected in HeLa cells [19] Apoptosis can be also induced via controlling the expression of Bcl2 family as shown in lung cancer and bladder cancer by mir-133b [48]. MiR-133b can affect cell proliferation and apoptosis through suppressing c-Met signaling pathways in colorectal carcinoma [49]. Previous study showed that miR$133 \mathrm{~b}$ can inhibit target gene silent information regulator 1 (Sirt1) that lead to suppression of cell proliferation and invasion in hepatocellular carcinoma [50] . Down-regulation of miR-133b was significantly correlated with primary resistance ovarian carcinomas [51] which refers to its crucial role in chemotherapeutic efficacy of cancer. On the other hand, a recent study showed that miR$133 \mathrm{~b}$ can reduce the phosphorylation of Erk1/2 and Akt by targeting EGFR in ovarian cancer [21]

The role of miR-26a-5p in carcinogenesis appears to be morecomplicated as it has both oncogenic and tumor suppressive effect in cancers including hepatocellular carcinoma cells [39]. Using HDAC inhibitor, up-regulation of miR-26a was recorded in human umbilical cord-blood multipotent stem cells (hUCB-MSCs) that plays important roles in cellular senescence via targeting highmobility group A2 protein (HMGA2) [52]. It was shown that miR-26a acts as tumor suppressor in a variety of cancers [53,54]. MiR-26a-5p is often downregulated in several tumor tissues and tumor cell lines [54]. MiR-26a was able to suppress the proliferation, migration, and invasion of cells via negative regulation of MTDH, which supported the role of miR-26a as tumor suppressor in HCC cells [55]. In addition, it was found that miR-26a has the potency to suppress tumor growth and metastasis by regulating FGF9 [56]. On the other hand, miR-26a was found to enhance metastasis of lung cancer by directly targetingthe tumor suppressor PTEN and thusactivating AKT signaling pathway [26].

Our results showed a down regulation of miR26a at low doses treatment (IC20 and IC35) whereas it was up regulated at high doses (IC50) in hepatocellular cells which is correlated with inhibition of cell proliferation. This might be due to thedual effect of SB, which means low concentrations of $\mathrm{SB}$ can produce a significant increase in cell growth in cell line, while unlikeness high concentrations of it can inhibit cell growth in the same cell line [57].

MiR-122-5p has been found to be closely associated with HCC [58]. In this study, we found that miR-122-5p was significantly down regulated in HepG2 and Huh7 cells treated with different concentrations of SB compared to control cells. Down expression of miR-122-5p was reported to cause inhibition of HCC cell proliferation, migration, and invasion by the targeting of IGF1R, MAPK11 and BCL2L2. BCL2L2 is one of the main inhibitors to intrinsic apoptotic pathway by reducing the activation of some essential pathways, such as cMyc, IGF, and Wnt//3-catenin [59]. MiR-122-5p inhibits Akt3, which regulates many processes including metabolism, proliferation, cell survival, growth and angiogenesis [60]. The metastatic and invasive property of HCC cells was also demonstrated to be suppressed by miR-122 in an ADAM17-dependent mechanism [31]. In addition, other studies revealed that miR-122 can induce apoptosis by inhibiting Bcl-w transcription [61]

Although miR-539-5p has been shown to be involved in other types of cancers, our study showed significant downregulation in both cells treated with different concentrations of SB compared with untreated cells. Other studies reported that miR-539-5p was downregulated inosteosarcoma and suppresses tumor metastasis by targeting MMP8 and acts as an oncogene or tumor suppressor in different types of cancer [62]

MiR-518f-3p was significantly up regulated in HepG2 and Huh7 cells treated with different concentrations of SB compared with untreated cells, which is in agreement withone studythat showed a significant up-regulationof miR-5 18f-3p in HCC [63] . According tomiRTarebaseand Gene Cards database miT-518f-3p inhibited TYRO3 and RPS6KA3. Other studies showed that TYRO3 
iscontrolling cell survival and proliferation in breast cancer [64]. Further studies are required to understand the possible role of miR-518f-3p in HCC.

Taken together, our results suggested that the biological effects at different concentrations of SBmight have different mechanisms at the cellular machinery level. Further studies are neededto elucidate this observationand its potent therapeutic effectsfor HCC.

\section{References}

1- CAPONE F., GUERRIERO E., SORICE A., et al.: Synergistic antitumor effect of doxorubicin and tacrolimus (FK506) on hepatocellular carcinoma cell lines. Scientific World Journal, 9: 450390, 2014.

2- RAMAKRISHNA G., RASTOGI A., TREHANPATI N., SEN B., KHOSLA R. and SARIN S.K.: From cirrhosis to hepatocellular carcinoma: New molecular insights on inflammation and cellular senescence. Liver cancer, 2 (34): 367-83, 2013

3- KUMAR M., SONG H.J., CHO S.K., BALASUBRAMANIAN S., CHOE S.Y. and RHO G.J.: Effect of histone acetylation modification with sodium butyrate, a histone deacetylase inhibitor, on cell cycle, apoptosis, ploidy and gene expression in porcine fetal fibroblasts. Journal of Reproduction and Development, 53 (4): 903-13, 2007.

4- HERCEG Z. and HAINAUT P.: Genetic and epigenetic alterations as biomarkers for cancer detection, diagnosis and prognosis. Molecular Oncology, 1 (1): 26-41, 2007.

5- ORCHEL A., DZIERZEWICZ Z., PARFINIEWICZ B., WEGLARZ L. and WILCZOK T.: Butyrate-induced differentiation of colon cancer cells is PKC and JNK dependent. Digestive Diseases and Science, 50 (3): 490-8, 2005.

6- SALIMI V., SHAHSAVARI Z., SAFIZADEH B., HOSSEINI A., KHADEMIAN N. and TAVAKOLI-YARAKI M.: Sodium butyrate promotes apoptosis in breast cancer cells through Reactive Oxygen Species (ROS) formation and mitochondrial impairment. Lipids Health Diseases, 16 (1): 208, 2017.

7- SHIN H., LEE Y.S. and LEE Y.C.: Sodium butyrateinduced DAPK-mediated apoptosis in human gastric cancer cells. Oncology Reports, 27 (4): 1111-5, 2012.

8- HAGUE A., MANNING A.M., HANLON K.A., HART D., PARASKEVA C. and HUSCHTSCHA L.I.: Sodium butyrate induces apoptosis in human colonic tumour cell lines in a p53-independent pathway: Implications for the possible role of dietary fibre in the prevention of largebowel cancer. International Journal of Cancer, 55 (3): 498-505, 1993.

9- MU D., GAO Z., GUO H., ZHOU G. and SUN B.: Sodium butyrate induces growth inhibition and apoptosis in human prostate cancer DU145 cells by up-regulation of the expression of annexin A1. PLoS One, 8 (9): e74922, 2013.

10- XIE C., WU B., CHEN B., et al.: Histone deacetylase inhibitor sodium butyrate suppresses proliferation and promotes apoptosis in osteosarcoma cells by regulation of the MDM2-p53 signaling. Onco Targets Therapy, 9: 4005-13, 2016.
11- JOACHIMIAK R., KAZNICA A. and DREWA T.: Influence of sodium butyrate on hepatocellular carcinoma (HepG2) and glioblastoma (C6) cell lines in vitro. Acta Polonoia Pharmacutica-Drug Research, 64 (6): 561-63, 2007.

12-KIM H.S., SHEN Q. and NAM S.W.: Histone Deacetylases and Their Regulatory MicroRNAs in Hepatocarcinogenesis. Journal of Korean Medical Science, 30 (10): 137580, 2015.

13- MOGNATO M. and CELOTTI L.: MicroRNAs Used in Combination with Anti-Cancer Treatments Can Enhance Therapy Efficacy. Mini Reviews in Medical Chemistry, 15 (13): 1052-62, 2015.

14- SKEHAN P., STORENG R., SCUDIERO D., et al.: New colorimetric cytotoxicity assay for anticancer-drug screening. Journal of Natl Cancer Inst., 82 (13): 1107-12, 1990.

15-LIVAK K.J. and SCHMITTGEN T.D.: Analysis of Relative Gene Expression Data Using Real-Time Quantitative PCR and the $2^{-}{ }^{-}$CT Method. Methods, 25 (4): 402-8, 2001.

16- CRAWFORD M., BATTE K., YU L., et al.: MicroRNA 133B targets pro-survival molecules MCL-1 and BCL2L2 in lung cancer. Biochem. Biophys. Res. Commun., 388 (3): 483-9, 2009.

17- GUO Y., LI X., LIN C., et al.: MicroRNA-133b inhibits connective tissue growth factor in colorectal cancer and correlates with the clinical stage of the disease. Molecular Medicine Reports, 11 (4): 2805-12, 2015.

18- HUANG M.B., XU H., XIE S.J., ZHOU H. and QU L.H.: Insulin-like growth factor-1 receptor is regulated by microRNA-133 during skeletal myogenesis. PLoS One, 6 (12): e29173, 2011.

19- PATRON J.P., FENDLER A., BILD M., et al.: Mir-133b targets antiapoptotic genes and enhances death receptorinduced apoptosis. Kok K-H, ed. PLoS One, 7 (4): e35345, 2012.

20- KANO M., SEKI N., KIKKAWA N., et al.: miR-145, miR-133a and miR-133b: Tumor-suppressive miRNAs target FSCN1 in esophageal squamous cell carcinoma. International Journal of Cancer, 127 (12): 2804-14, 2010.

21- LIU X. and LI G.: MicroRNA-133b inhibits proliferation and invasion of ovarian cancer cells through Akt and Erk1 /2 inactivation by targeting epidermal growth factor receptor. International Journal of Clinical and Experiment Pathology, 8 (9): 10605-14, 2015.

22- KARATAS O.F., GUZEL E., SUER I., et al.: miR-1 and miR-133b are differentially expressed in patients with recurrent prostate cancer. PLoS One, 9 (6): e98675, 2014.

23- LI D., XIA L., CHEN M., et al.: miR-133b, a particular member of myomiRs, coming into playing its unique pathological role in human cancer. Oncotarget, 8 (30): 50193-208, 2017.

24- YAO C., SUN M., YUAN Q., et al.: MiRNA-133b promotes the proliferation of human Sertoli cells through targeting GLI3. Oncotarget, 7 (3): 2201-19, 2016.

25- ZHAO X.X., YUAN Q.Z., MU D.P., et al.: MicroRNA26a inhibits proliferation by targeting high mobility group AT-hook 1 in breast cancer. International Journal of Clinical and Experimental Pathology, 8 (1): 368-73, 2015. 
26- LIU B., WU X., LIU B., et al.: MiR-26a enhances metastasis potential of lung cancer cells via AKT pathway by targeting PTEN. Biochim. Biophys. Acta-Molecular Basis of Diseases, 1822 (11): 1692-704, 2012.

27- QIAN H., YANG C. and YANG Y.: MicroRNA-26a inhibits the growth and invasiveness of malignant melanoma and directly targets on MITF gene. Cell death Discovery, 3: 17028, 2017.

28- SI Y., ZHANG H., NING T., et al.: MiR-26a/b Inhibit Tumor Growth and Angiogenesis by Targeting the HGFVEGF Axis in Gastric Carcinoma. Cellular Physiology and Biochemistry, 42 (4): 1670-83, 2017.

29- POTTS M.B., KIM H.S., FISHER K.W., et al.: Using functional signature ontology (FUSION) to identify mechanisms of action for Natural products. Science Signaling, 6 (297), 2013.

30- WANG B., WANG H. and YANG Z.: MiR-122 Inhibits Cell Proliferation and Tumorigenesis of Breast Cancer by Targeting IGF1R. Mukhopadhyay P, ed. PLoS One, 7 (10): e47053, 2012.

31- TSAI W.C., HSU P.W.C., LAI T.C., et al.: MicroRNA122 , a tumor suppressor microRNA that regulates intrahepatic metastasis of hepatocellular carcinoma. Hepatology, 49 (5): 1571-82, 2009.

32- NASSIRPOUR R., MEHTA P.P. and YIN M.J.: miR-122 Regulates Tumorigenesis in Hepatocellular Carcinoma by Targeting AKT3. Cheng. J.Q., ed. PLoS One, 8 (11): e79655, 2013.

33- RAITOHARJU E., SEPPÄLÄ I., LYYTIKÄINEN L.P., et al.: Blood hsa-miR-122-5p and hsa-miR-885-5p levels associate with fatty liver and related lipoprotein metabolism-The Young Finns Study. Science Reports, 6 (1): 38262, 2016.

34- NAIRISMÄGI M.L., FÜCHTBAUER A., LABOURIAU R., BRAMSEN J.B. and FÜCHTBAUER E.M.: The protooncogene TWIST1 is regulated by microRNAs. PLoS One, 8 (5): e66070 2013.

35- ABBA M., PATIL N., LEUPOLD J. and ALLGAYER H.: MicroRNA Regulation of Epithelial to Mesenchymal Transition. Journal of Clinical Medicine, 5 (1): 8, 2016.

36- HAFNER M., LANDTHALER M., BURGER L., et al.: Transcriptome-wide identification of RNA-binding protein and microRNA target sites by PAR-CLIP. Cell, 141 (1): 129-41, 2010.

37- BOURASSA M.W., ALIM I., BULTMAN S.J. and RATAN R.R.: Butyrate, neuroepigenetics and the gut microbiome: Can a high fiber diet improve brain health? Neuroscience Letter, 625: 56-63, 2016.

38- CHO J.H., DIMRI M. and DIMRI G.P.: MicroRNA-31 is a transcriptional target of histone deacetylase inhibitors and a regulator of cellular senescence. Journal of Biological Chemistry, 290 (16): 10555-67, 2015.

39- ZhANG Y.C., XU Z., ZHANG T.F. and WANG Y.L.: Circulating microRNAs as diagnostic and prognostic tools for hepatocellular carcinoma. World Journal of Gastroenterol, 21 (34): 9853-62, 2015.

40- TAKIMOTO R., KATO J., TERUI T., et al.: Augmentation of antitumor effects of p53 Gene therapy by combination with HDAC inhibitor. Cancer Biology Therapy, 4 (4): 427-34, 2005.
41- BRITO A.F., ABRANTES A.M., PINTO-COSTA C., et al.: Hepatocellular carcinoma and chemotherapy: The role of p53. Chemotherapy, 58 (5): 381-6, 2012.

42- HANDY D.E., CASTRO R. and LOSCALZO J.: Epigenetic modifications: Basic mechanisms and role in cardiovascular disease. Circulation, 123 (19): 2145-56, 2011.

43- CHUANG J.C. and JONES P.A.: Epigenetics and microRNAs. Pediatric Research, 61: 24R-29R, 2007.

44- SAITO Y., SAITO H., LIANG G. and FRIEDMAN J.M.: Epigenetic alterations and microRNA misexpression in cancer and autoimmune diseases: A critical review. Clinical Reviews in Allergy and Immunology, 47 (2): 128-35, 2014.

45- CHEN S.W., WANG T.B., TIAN Y.H. and ZHENG Y.G.: Down-regulation of microRNA-126 and microRNA-133b acts as novel predictor biomarkers in progression and metastasis of non small cell lung cancer. International Journal of Clinincal and Experimental Pathology, 8 (11): 14983-8, 2015.

46- CHEN X., WU B., XU Z., et al.: Downregulation of miR$133 \mathrm{~b}$ predict progression and poor prognosis in patients with urothelial carcinoma of bladder. Cancer Medicine, 5 (8): 1856-62, 2016.

47- AKCAKAYA P., EKELUND S., KOLOSENKO I., et al.: miR-185 and miR-133b deregulation is associated with overall survival and metastasis in colorectal cancer. International Journal of Oncology, 39 (2): 311-8, 2011.

48- CHEN S., PUTHANVEETIL P., FENG B., MATKOVICH S.J., DORN G.W. and CHAKRABARTI S.: Cardiac miR133a overexpression prevents early cardiac fibrosis in diabetes. Journal of Cellular and Molecular Medicine, 18 (3): 415-21, 2014.

49- HU G., CHEN D., LI X., YANG K., WANG H. and WU $\mathrm{W} .:$ miR-133b regulates the MET proto-oncogene and inhibits the growth of colorectal cancer cells in vitro and in vivo. Cancer Biology Therapy, 10 (2): 190-7, 2010.

50- TIAN Z., JIANG H., LIU Y., et al.: MicroRNA-133b inhibits hepatocellular carcinoma cell progression by targeting Sirt1. Experimental Cell Research, 343 (2): 13547, 2016.

51- CHEN S., JIAO J.W., SUN K.X., ZONG Z.H. and ZHAO Y.: MicroRNA-133b targets glutathione S-transferase $\Pi$ expression to increase ovarian cancer cell sensitivity to chemotherapy drugs. Drug Design Development and Theapy, 9: 5225-35, 2015.

52- LEE S., JUNG J.W., PARK S.B., et al.: Histone deacetylase regulates high mobility group A2-targeting microRNAs in human cord blood-derived multipotent stem cell aging. Cellular and Molecular Life Science, 68 (2): 325-36, 2011.

53- MIYAMOTO K., SEKI N., MATSUSHITA R., et al.: Tumour-suppressive miRNA-26a-5p and miR-26b-5p inhibit cell aggressiveness by regulating PLOD2 in bladder cancer. British Journal of Cancer, 115 (3): 354-63, 2016.

54- RIZZO M., BERTI G., RUSSO F., et al.: Discovering the miR-26a-5p targetome in prostate cancer cells. Journal of Cancer, 8 (14): 2729-39, 2017.

55- YANG C., ZHENG S., LIU T., et al.: Down-regulated miR-26a promotes proliferation, migration, and invasion 
via negative regulation of MTDH in esophageal squamous cell carcinoma. FASEB Journal, 31 (5): 2114-22, 2017.

56- DENG M., TANG H. LIN, LU X. HONG, et al.: miR-26a Suppresses Tumor Growth and Metastasis by Targeting FGF9 in Gastric Cancer. Sun HS, ed. PLoS One, 8 (8): e72662, 2013.

57- JIANG W., GUO Q., WU J., et al.: Dual effects of sodium butyrate on hepatocellular carcinoma cells. Molecular Biology Reports, 39 (5): 6235-42, 2012.

58- COULOUARN C., FACTOR V.M., ANDERSEN J.B., DURKIN M.E. and THORGEIRSSON S.S.: Loss of miR122 expression in liver cancer correlates with suppression of the hepatic phenotype and gain of metastatic properties. Oncogene, 28 (40): 3526-36, 2009.

59- WANG G., ZHAO Y., ZHENG Y.: miR-122/Wnt/ $\beta$-catenin regulatory circuitry sustains glioma progression. Tumor Biology, 35 (9): 8565-72, 2014.
60- WANG H., GAO H., DUAN S. and SONG X.: Inhibition of microRNA-199a-5p reduces the replication of HCV via regulating the pro-survival pathway. Virus Research, 208: 7-12, 2015.

61- LIN C.J.F., GONG H.Y., TSENG H.C., WANG W.L. and WU J.L.: Biochemical and Biophysical Research Communications. Vol. 375, 2009.

62- ZHOU K., LIU M. and CAO Y.: New Insight into microRNA Functions in Cancer: Oncogene-microRNA-Tumor Suppressor Gene Network. Front Molecular Bioscience, 4: 46, 2017.

63- TOFFANIN S., HOSHIDA Y., LACHENMAYER A., et al.: MicroRNA-Based Classification of Hepatocellular Carcinoma and Oncogenic Role of miR-517a. Gastroenterology, 140 (5): 1618-28.e16, 2011.

64- EKYALONGO R.C., MUKOHARA T., FUNAKOSHI Y., et al.: TYRO3 as a potential therapeutic target in breast cancer. Anticancer Research, 34 (7): 3337-45, 2014.

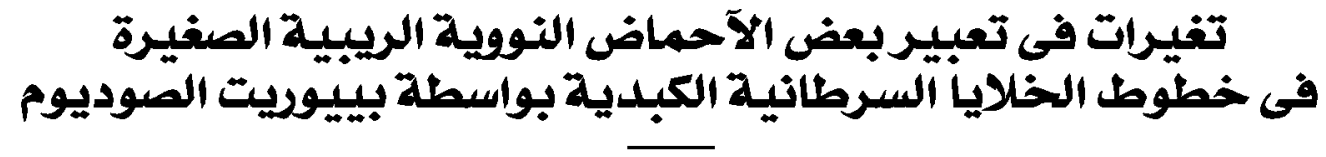

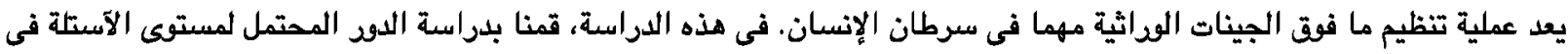

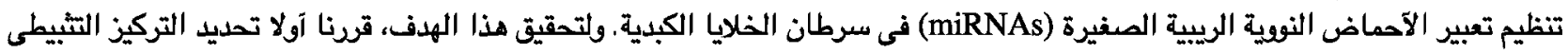

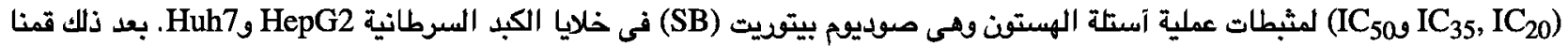
miR-26a-5p, miE-122-5p, miR-133b) مثحليل معستى التعبير لعدد خمسة من الآحناض النوية الريبية الصغيرة (miRNAs) (miR-518f-3p بعد المعالجة بمادة بيتويت الصوديوم بإستخدام إختبار البلمرة المتسلسل miR-539-5p,

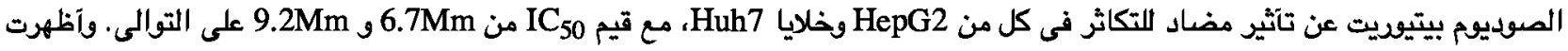

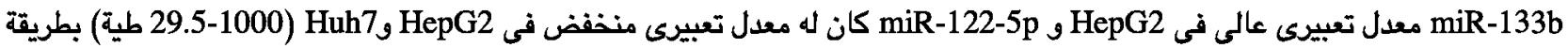

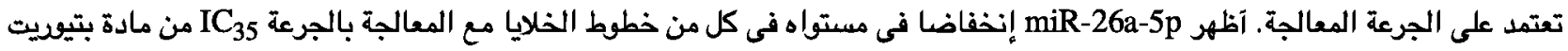

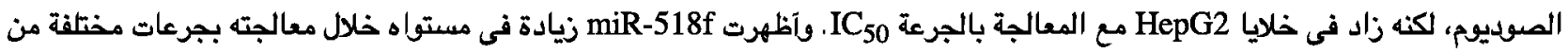
بيتيويت الصوديوم في كل من خطوط الخلايا ـ وآخيرا، آظهرت miR-539-5p إنخفاضا حادا في معدل تعبيرها في كل من خطوط في في الخلايا

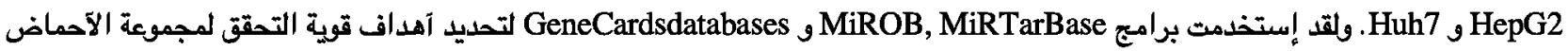
النوية الريبية الصغيرة التى تم فحصها microRNAs، والكشف عن الوظائف الممكنة من الآهداف المحددة والشبكات الوظيفية ذات الصلة. آشار تعليل الشبكات الوظيفية التنبؤ بالدود الهام لكل من miR-122-5p, miR-133b و miR-26a-5p في التكاثر الخلوى والإنقسام، التدمير

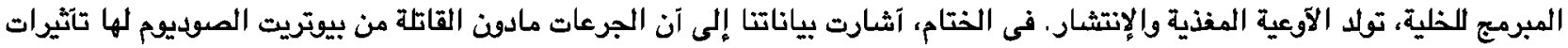

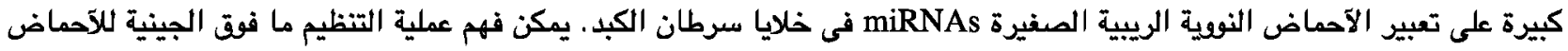

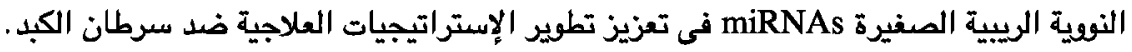

